\title{
Measuring radon in soil gas and groundwaters: a review
}

\author{
Constantin Papastefanou \\ Aristotle University of Thessaloniki, Atomic and Nuclear Physics Laboratory, Thessaloniki, Greece
}

\begin{abstract}
Instruments for the measurements of radon and its decay products in earthquake research are based mostly on the detection of alpha particles. The devices and methods used depend on whether the techniques measure radon or radon decay products, and the duration of the measurements, of which there are three types: i) grab or instantaneous, ii) integrating and iii) continuous. Other criteria used in the design of these instruments are field measurements applicability, portability, convenience and reliability. With the recent increased demand for radon and radon decay products measurements, instruments development has focused on the design of appropriate devices for short-term measurements, as well as on more complex and sophisticated instruments for long-term measurements used in radon research for geophysical, geochemical and hydrological studies.
\end{abstract}

Key words radon - soil gas - groundwaters earthquake prediction - instrumentation

\section{Introduction}

The radon content in soil gas exhaling from the ground surface as well as in underground waters (i.e. in waters from wells that are hundreds of meters deep and springs along active fault zones) is one of the few important earthquake precursors. Other earthquake precursors are water levelling (water discharge), water temperature, (geo)magnetic field and resistivity (electric resistance of the bed rock). The short-term precursors occur in periods ranging from a few days to several months, while the intermediate-term precursors range from a few years to ten or more years, and the long-term precursors range from several years to several decades before an earthquake episode (Wakita et al., 1988).

Mailing address: Prof. Constantin Papastefanou, Aristotle University of Thessaloniki, Atomic and Nuclear Physics Laboratory, Thessaloniki 54124, Greece; e-mail: papastefanou@physics.auth.gr
Detection of radon is important to earthquake prediction studies. Instruments for the measurement of radon and its decay products are based mostly on the detection of alpha particles, the energy of which ranged from 5.5 to $7.7 \mathrm{MeV}\left({ }^{222} \mathrm{Rn}\right.$ 5.5 MeV, ${ }^{218}$ Po 6.0 MeV, ${ }^{214} \mathrm{Po} 7.7 \mathrm{MeV}$ ). The instruments and methods used depend on whether radon or its decay products are measured. Regarding the duration of measurements, there are three types of measurements: i) grab or instantaneous, ii) integrating and iii) continuous. The radon sampling devices can be divided into active devices that require electric power to collect a sample and passive devices that do not require electric power (dry battery operated). Among the criteria used in the design of the instruments for measuring radon are field measurement applicability, portability, convenience, reliability and cost (George, 1990). For short-term radon exposures very simple devices are used, whereas there are more complex and sophisticated instruments for long-term radon measurements used in radon research.

The types of instruments and techniques used in the detection of either the alpha particles emitted by radon itself or the alpha particles of its decay products are the following: 
Table I. Specific data of radon measurements devices.

\begin{tabular}{|c|c|c|c|c|c|}
\hline Method & Type & Field area & Volume & Sensitivity & Time period \\
\hline Alpha scintillation detectors & Instantaneous & Gas/water & $0.11-3.01$ & $0.8-16 \mathrm{cph} / \mathrm{Bq} \mathrm{m}^{-3}$ & $1-5 \mathrm{~min}$ \\
\hline Alpha track-etch detectors & Integrated & Gas & $456 \mathrm{ml}$ & $\begin{array}{l}0.03-0.09 \text { tracks } \\
\mathrm{cm}^{-2} / \mathrm{kBq} \mathrm{m}^{-3} \mathrm{~h}\end{array}$ & 1-2 weeks \\
\hline Electret ion chambers & Integrated & Gas & $50 \mathrm{ml}-960 \mathrm{ml}$ & $3 \mathrm{~Bq} \mathrm{~m}^{-3} \mathrm{~h}-1.05 \mathrm{kBq} \mathrm{m}^{-3} \mathrm{~h}$ & h 2-40 days \\
\hline Barasol detectors & Continuous & Gas & $590 \mathrm{ml}$ & 0.02 pulses $\mathrm{h}^{-1} / \mathrm{Bq} \mathrm{m}^{-3}$ & $15-240 \mathrm{~min}$ \\
\hline Clipperton detectors & Continuous & Water & $590 \mathrm{ml}$ & $1 \mathrm{cph} / 362 \mathrm{~Bq} \mathrm{~m}^{-3}$ & $1 \mathrm{~min}-48 \mathrm{~h}$ \\
\hline Radon/thoron monitors & Continuous & Gas/water & 0.271 & $0.01 \mathrm{cpm} / \mathrm{Bq} \mathrm{m}^{-3}$ & $\begin{array}{c}1 \mathrm{~min}-24 \mathrm{~h} \\
\text { (standard } 6 \mathrm{~min} \text { ) }\end{array}$ \\
\hline
\end{tabular}

1 - Alpha scintillation detectors such as zincsulfide phosphors, silver activated, $\mathrm{ZnS}(\mathrm{Ag})$.

2 - Alpha track-etch detectors, ATDs or solid state nuclear track-etch detectors, SSNTDs, for registering of nuclear of alpha particles in solid-state materials.

3 - Alpha radiation spectrometers with silicon diode, either surface barrier or diffused junction detectors.

This paper is an overview of instrumentation for measuring environmental radon in soil gas and groundwaters for geophysical, geochemical and hydrological studies. A summary of the specific data of radon measurement devices are presented in table I.

\section{Measurement of radon by grab sampling}

The scintillation cell method is one of the oldest and most widely used for grab sampling of radon and its decay products in the field. Scintillation cells (e.g., Lucas cells) or scintillation flasks (Environmental Measurements Laboratory - EML produced) range in size from 0.09 to 3.01 and they are made by using metal, glass or plastic containers coated internally with silver activated, $\mathrm{ZnS}(\mathrm{Ag})$ powder. The bottom of the container in cylindrical form is usually transparent to allow light photons produced in the scintillator to be detected. If the internal coating is very thin, the bottom of the container can also be coated without significant loss of light photons. For counting the light photons, the scintillation cell is coupled to a photomultiplier tube assembly system.
The principle of detection is the counting of light photons resulting from the interaction of alpha particles from radon and its decay products decaying in the cell with the $\mathrm{ZnS}(\mathrm{Ag})$ phosphor. $\mathrm{ZnS}(\mathrm{Ag})$ emits light in the range of $450 \mathrm{~nm}$ (visible spectrum), so photomultiplier tubes with a peak response near this wavelength are generally used. Scintillation cells can be filled by exposing evacuated cells (instantaneous), or by flowing air through at ambient conditions for 1-5 min.

The advantage of using a scintillation cell is that it eliminates the need for sample transfer before counting. However, samples from larger containers or from systems that concentrate environmental levels of radon (that from soil gas) by cryogenic processes can be transferred into them for counting if desired. Measurement errors using scintillation cells can result from improper calibration, leaking cells and malfunctioning or an improperly calibrated photomultiplier tube system. Calibrations with a particular scintillation cell-photomultiplier tube system should not be another calibration unless both systems are crosscalibrated. The calibration radon gas sources consisted of a 201 radon $\left({ }^{222} \mathrm{Rn}\right)$ gas source and a 20 $\mathrm{ml}$ gas dispenser. This allows a large number of successive samples to be taken per day. The nominal source activity ranges from 3 to $18 \mathrm{kBq}$.

The sensitivities of scintillation cells range from 0.8 to $16 \mathrm{cph}$ per $\mathrm{Bq} \mathrm{m}^{-3}$ for sizes ranging from 0.11 to 3.01 , respectively. When properly maintained, scintillation cells can be reused for years after a very good cleaning with nitrogen gas (inert gas). 


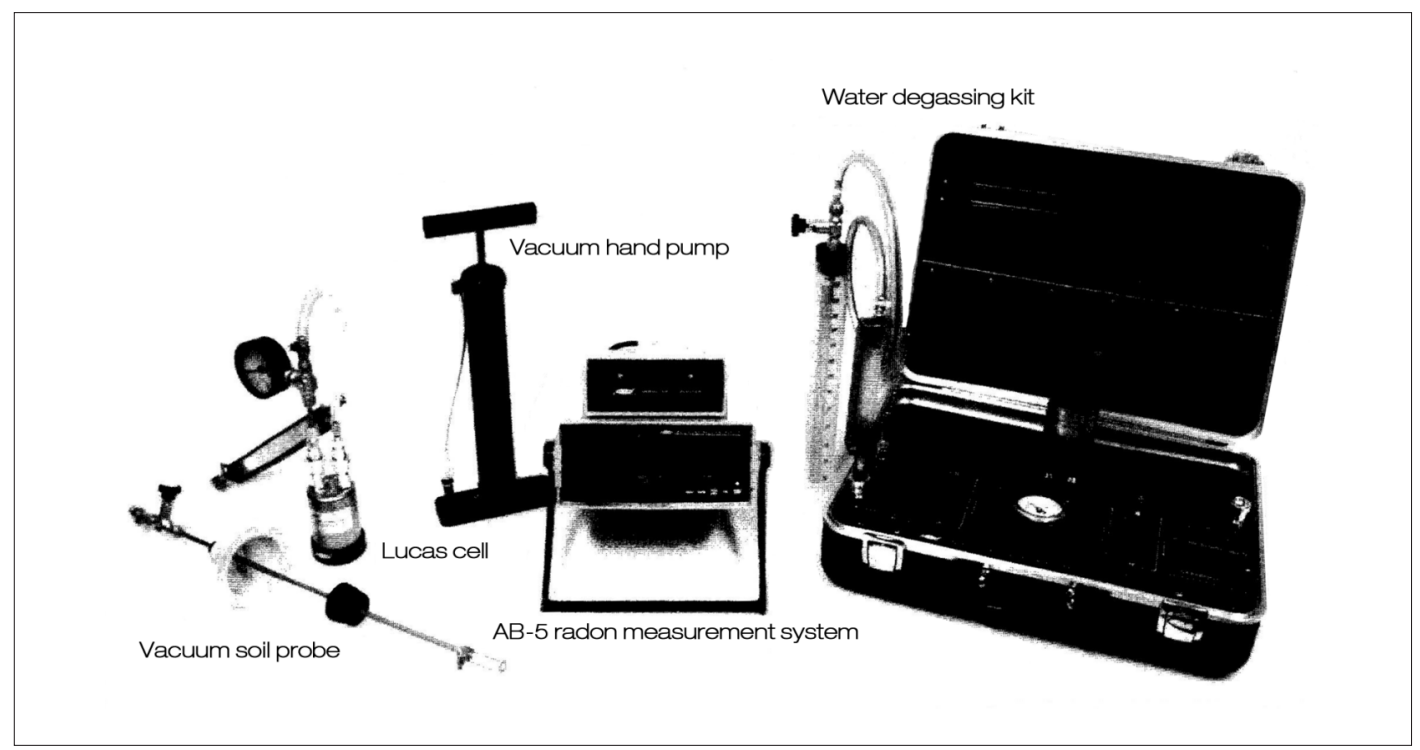

Fig. 1. Instrumentation for measuring radon in soil gas and groundwaters with alpha scintillation cells (PYLON, model AB-5, radon measurement system).

In the case of soil gas, the gas is pulled off at opened holes of 70 to $100 \mathrm{~cm}$ deep. For underground waters, a water degassing unit (kit) is used with a bubbler consisting of a triple stopcock valve to void any radon entry of atmospheric origin.

Figure 1 shows a complete system (PYLON Electronics Inc., 147 Colonnade Read, Ottawa, Ontario, Canada) of radon measurement in soil gas and groundwaters with other grab sampling containers from which a sample can be transferred into a scintillation cell for alpha counting. The unit was linked to a portable radon monitor with a trace level detector and data aquisition unit. The background of the radon monitor was $0.4 \mathrm{cpm}$ or $24 \mathrm{cph}$. The maximum count rate was $10^{6}$ counts per second.

\section{Passive integrating methods of radon measurement by solid-state nuclear track-etch detectors (SSNTDs)}

The principle of radon detection by solid-state nuclear track-etch detectors is based on the pro- duction of alpha particle tracks in solid-state materials, such as cellulose nitrate films LR-115, type II, non-strippable (Kodak Pathé Co., F93270 Sevran, France) and allyl diglycol carbonate plastic films CR-39 (Pershore Mouldings Ltd., Worcestershire WR10 2DH, England) (Alter and Fleischer, 1981). The plastic detector is usually placed inside a cylindrical tube of $44 \mathrm{~mm}$ inner diameter, $50 \mathrm{~mm}$ outer diameter and $300 \mathrm{~mm}$ in length. The detectors are on the top of the tube, held appropriately by a wire clip. The plastic tube with the plastic radon detector is set inside a larger plastic tube (1000 mm in length and $70 \mathrm{~mm}$ inner diameter). The empty space between the two plastic tubes is filled with styrofoam material in granule pellet form to thermally isolate the volume of the radon tube (chamber). To avoid humidity effects on registration of alpha particles to the detector's surface (Papastefanou et al., 2002), a glass fiber filter was placed in front of the plastic detector (fig. 2) that also prevents alpha particles originating from radon decay products from reaching on the detector's surface.

Alpha particles from radon produced inside the volume of the inner tube (the chamber) irradi- 
ate the plastic detector and produce damage tracks. After exposure of about 7 to 9 days, the tracks are made visible either by chemical or electrochemical etching, usually in $\mathrm{NaOH}$ or $\mathrm{KOH}$ solution. Electrochemical etching is preferable because it produces large-diameter tracks and simplifies track counting. The track density is determined either by manual scanning and counting (jumping spark counter) or by an automated optical scanning system (video image analyser).

The alpha track method of radon measurement is relatively intensive. Therefore, under normal environmental field conditions exposure periods in boreholes range from 1 to 2 weeks. For this reason, alpha track detectors are preferred in situations where confirmation of measurements made with short-term integrating devices is needed. The sensitivity of alpha track-etch detectors ranges from 0.03 (for LR-115) to 0.09 (for CR39) tracks $\mathrm{cm}^{-2}$ per $\mathrm{kBq} \mathrm{m}^{-3} \mathrm{~h}$. The lower limit of detection is 2 to $8 \mathrm{~Bq} \mathrm{~m}^{-3}$ depending on the size of the scanned area of the detector.

Some factors that may affect the performance of these detectors are variability in response of detectors from different production batches and from non-uniform plateout effects of the radon decay products inside the tube (the con- tainer or chamber). Because of the variability of solid-state nuclear track-etch detectors, i.e. the plastics (thickness, acquired background and temperature during preparation), exceptional product quality control is required. Also, quality assurance measurements must be in place, involving frequent calibrations for accuracy and duplicate exposures for precision estimates.

A schematic drawing of a device for radon measurement in soil gas by SSNTDs is shown in fig. 2. A spectrum (histogram) of radon concentrations obtained by an integrating radon monitoring device with SSNTDs for the period of December 1996 through June 2000 at two different locations $\mathrm{E}$ and $\mathrm{Z}$ at the Gerakarou area in the Langadas Basin, Northern Greece (Papastefanou et al., 2002) is illustrated in fig. 3 . Well-defined peaks of radon concentrations are clearly shown.

Other materials used for registering alpha tracks are CN-85, previously called CA 80-15 (cellulose nitrate), PATRAS (poly-diethyleneglycol-bis) (allyl carbonate) equivalent to CR39, Bexford-190, Makrofol polycarbonate, Lurans plastic, Lexan, etc.

Other types of devices using SSNTDs are the Electret Ion Chambers (EIC - Rad Elec Inc.,

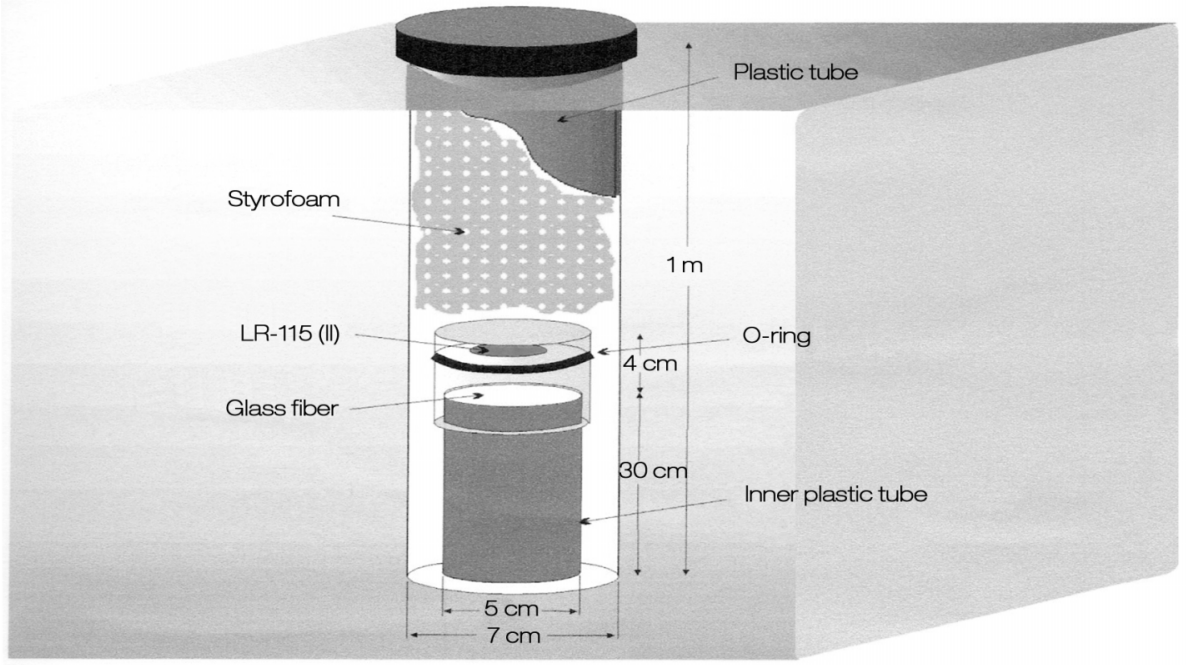

Fig. 2. A schematic drawing of a device for measuring radon in soil gas by Solid-State Nuclear Track-etch Detectors, SSNTDs. 


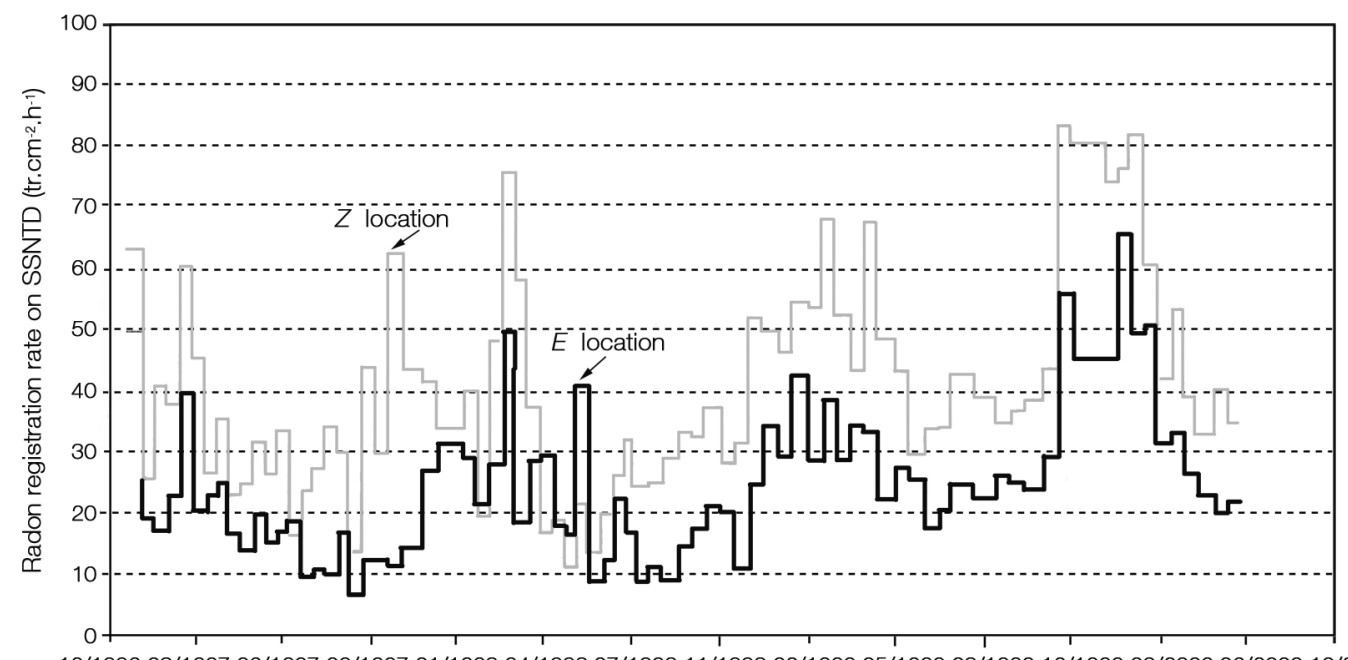

12/1996 03/1997 06/1997 09/1997 01/1998 04/1998 07/1998 11/1998 02/1999 05/1999 08/1999 12/1999 03/2000 06/2000 10/2000

$-E-Z$

Fig. 3. A spectrum (histogram) of radon concentrations in soil gas obtained by an integrating radon monitoring device with SSNTDs, at two different locations.
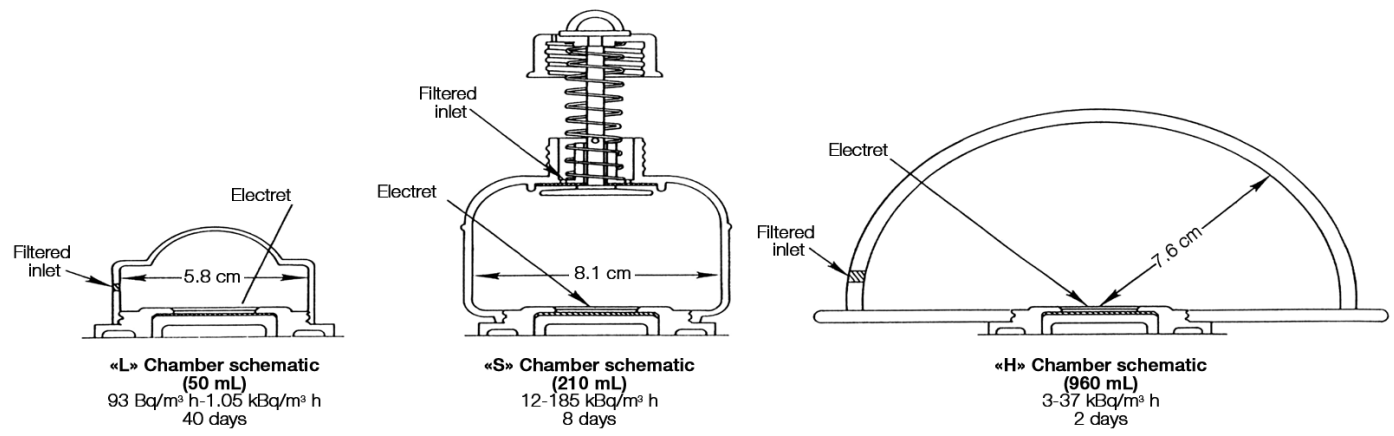

Fig. 4. A schematic view of different electret ion chambers as passive environmental radon monitors (E-PERM system). The volume, the sensitivity and the time period of measurements are noted.

5714-C Industry Lane, Frederick, MD 21704) as passive environmental radon monitors for the measurement of radon flux from the soil (Kotrappa et al., 1992), fig. 4. These are integrating ionization chambers wherein the electret (permanently charged Teflon disk) serves both as a source of electrostatic field and as a sensor. It consists of an electret mounted inside a small chamber made out of conducting plastic. The ions produced inside the chamber are collected onto the electret causing a reduction of the surface charge on the electret. The reduction in charge is a measure of the ionization intergrated over a period of exposure to alpha particles emitted by the decay process of radon gas and its decay products. The volume of the ionisation chamber ranges from 50 to $960 \mathrm{ml}$. The exposure periods range from 2 days to 40 days and 
the sensitivity of the detectors ranges from 3 $\mathrm{Bq} / \mathrm{m}^{3} \mathrm{~h}$ to $1.05 \mathrm{kBq} / \mathrm{m}^{3} \mathrm{~h}$ (fig. 4).

\section{Continuous radon monitors}

A continuous method for measuring radon is one where sampling and analysis occur simultaneously, providing real-time measurement results. This can be a very useful and desirable situation, e.g., in the field, particularly along active fault zones, where radon concentrations may change significantly and rapidly. These devices are also used to monitor radon exposure chambers used in research and for other instrument calibration and standardization. Measurement intervals generally range from a minimum of 1 to $15 \mathrm{~min}$ up to $48 \mathrm{~h}$. The primary advantage of continuous radon monitors is that they provide real-time radon concentration data on a frequent basis.

\subsection{Barasol detector}

Barasol (ALGADE, Route Nationale 2, F87250 Bessines-sur-Gartempe, France) detectors perform static measurements (without disturbance) of radon gas (Abbad et al., 1995; Pinault and Baubron, 1996; Trique et al., 1999). Measurement is provided by a silicon detector which records alpha particle emissions of the radon present in an optimised measurement chamber $(60 \mathrm{~mm}$ in diameter, $570 \mathrm{~mm}$ in length, and 0.7 to $0.8 \mathrm{~m}$ depth). The detector totalises alpha emissions generated during pre-established time intervals of 15 to $240 \mathrm{~min}$. A micro-processor is used to store the measured values. Readout is performed either by an on-site reader or by a PC-compatible computer with associated software.

The detector is a light tight implanted silicon junction (planar). It has protection against light by an alumimum layer and mechanical protection by a cellulose varnish. The useful area is $450 \mathrm{~mm}^{2}$ and the depleted depth of the detector is $100 \mu \mathrm{m}$. Resolution with the detector placed in the air is $60 \mathrm{keV}$ (FWHM) at 5.486 $\mathrm{MeV}\left({ }^{241} \mathrm{Am}\right)$ and the sensitivity is 0.02 pulses per hour for $1 \mathrm{~Bq} \mathrm{~m}^{-3}$. The saturation volumet- ric activity is $3 \mathrm{MBq} \mathrm{m}^{-3}$. The background count rate is below 1 event every $24 \mathrm{~h}$. The detection limit for radon is $50 \mathrm{~Bq} \mathrm{~m}^{-3}$.

The unit also measures atmospheric parameters such as temperature $\left(0.1^{\circ} \mathrm{C}\right.$ resolution for variation), atmospheric pressure (1 hPa resolution) and rain precipitation ( $0.1 \mathrm{~mm}$ resolution). It also has the possibility to permit «real time» tracking of radon measurements all over the world using a modem, or satellite modules, with a one-year autonomy from two $D$ type alkaline batteries.

Figure 5 shows a schematic of a barasol device for continuous measurements of radon volumetric activity in soil gas. A spectrum of radon concentrations in soil gas obtained by a barasol detector with meteorological parameters such as temperature, barometric pressure and rainfall

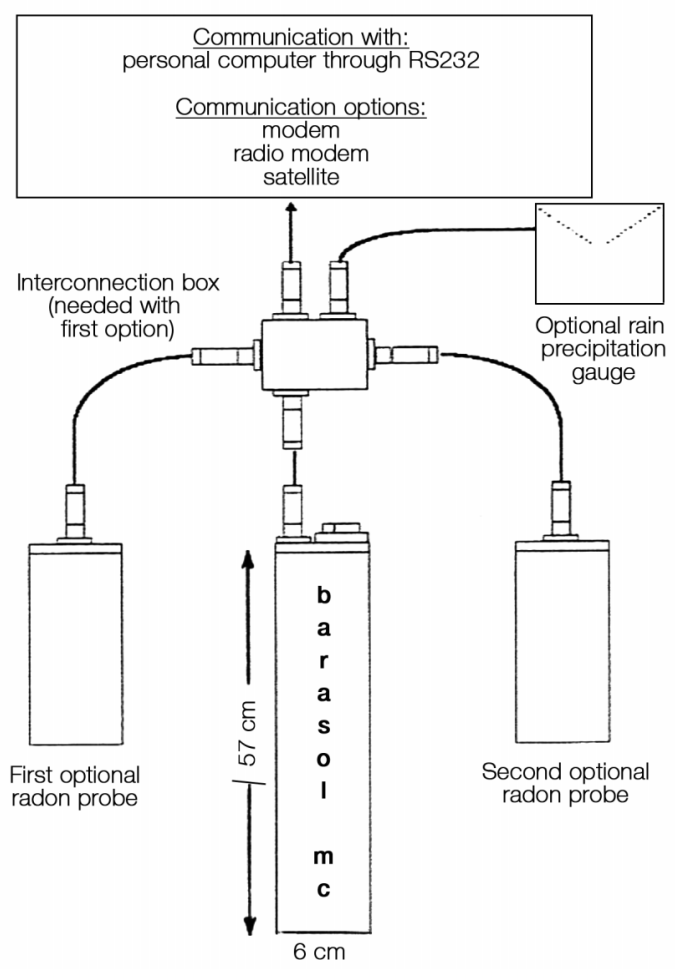

Fig. 5. A schematic view of a barasol device for continuous measurements of radon volumic activity in soil gas (ALGADE barasol mc). 


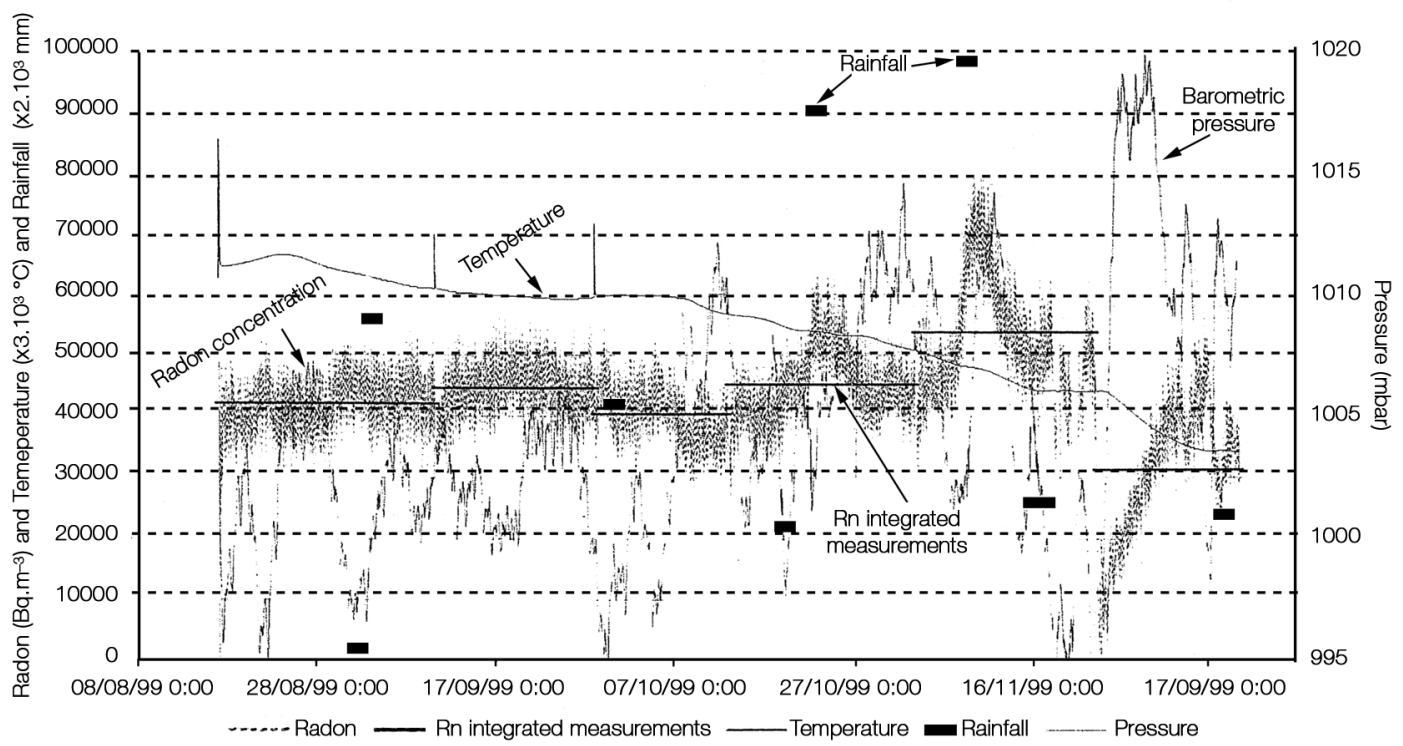

Fig. 6. A spectrum of radon concentrations obtained by a barasol detector of radon in soil gas. The meteorological parameters, such as temperature, barometric pressure and rainfall are also included.

for the period of August through December 1999 at the Stivos area in the Langadas Basin, Northern Greece (Papastefanou et al., 2002) is illustrated in fig. 6 .

\subsection{Clipperton detector}

Continuous radon concentrations in groundwaters are monitored by means of an electronic automatic probe, called Clipperton (CNRSURA 1767, Universite Montpellier II, F-34095 Montpellier, France) (Pane et al., 1995). It is based on a silicon diode detector associated with electronic data processing and storage unit of low consumption (four LR20 alkaline batteries that operate for 6 months). The probe consists of a $5-\mathrm{cm}$ diameter $(50 \mathrm{~cm}$ length) waterproof tube containing the detector together with the pre-amplifier, amplifier, discriminator, data processing and storage units. The diode and the electronics are specially protected against humidity. The tube is provided with a diffusion membrane at its opening to avoid thoron contribution and water condensation on the diode.
The batteries are placed in an external waterproof casement. The sensitivity of the detector is 1 count $h^{-1}=362 \mathrm{~Bq} \mathrm{~m}^{-3}$. The time monitoring period is fixed by the operator in a range of 1 min to $48 \mathrm{~h}$. Data extraction is performed in the field on a lap-top micro-computer by means of an EPROM memory.

Figure 7 shows a schematic drawing of a Clipperton probe for continuous measurements in groundwaters.

\subsection{Radon/thoron monitor}

The radon/thoron monitor (SARAD GmbH, Wiesbadener Str. 20, D-01159 Dresden, Germany) is a microsystem based monitoring system for the measurement of radon and thoron in soil gas and groundwaters. The radon/thoron monitoring system (Streil et al., 1997a) consists of a measuring chamber with electrostatic radon/thoron decay products being collected on a sensor chip. The microcontrolled instrument works continuously with various time resolutions ranging from $1 \mathrm{~min}$ up to $24 \mathrm{~h}$. The sys- 


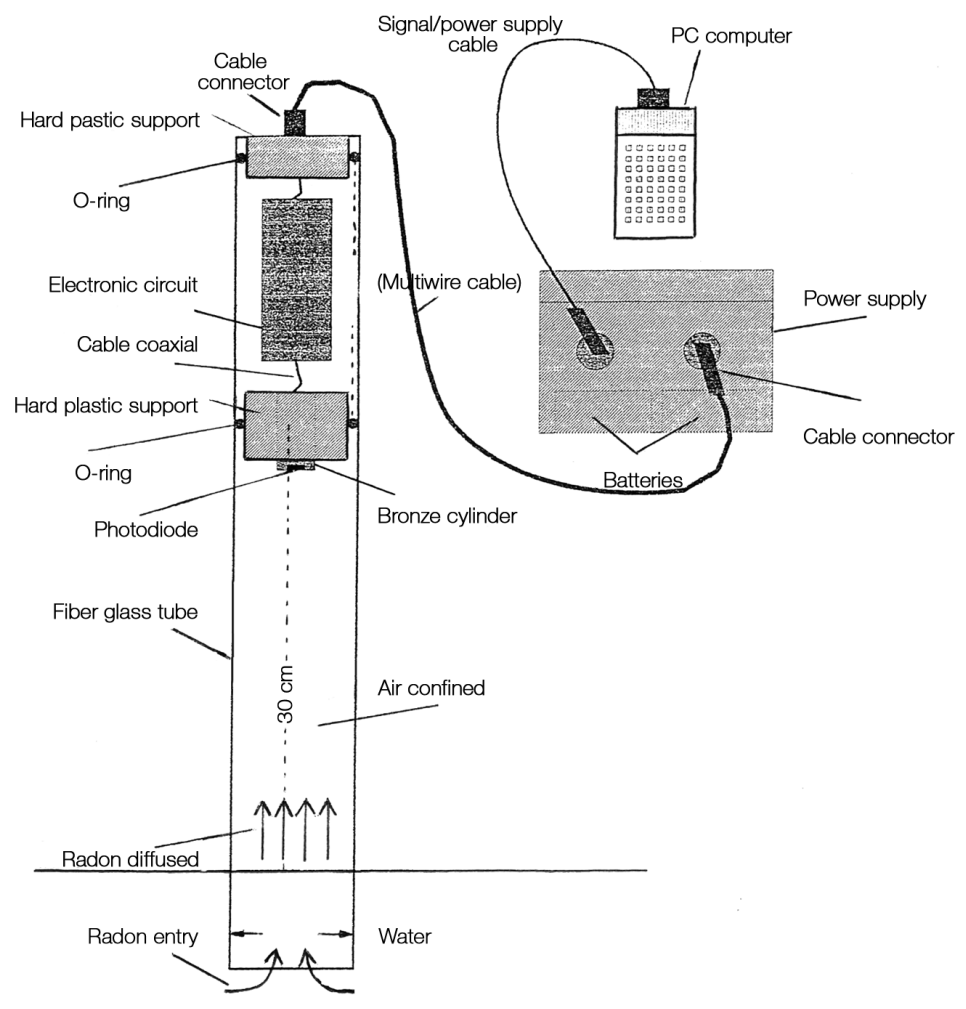

Fig. 7. A schematic drawing of a Clipperton probe for continuous radon measurements in groundwaters.

tem pumps soil gas, with a gas flow rate from 0.4 up to 31 per minute, through the monitor and collects the radon and thoron decay products on a foil above the silicon detector. It then analyses the time dependence and the spectrometric information of the radon and thoron decay products concentration. The measurement intervals are chosen from $1 \mathrm{~min}$ to $24 \mathrm{~h}$, with a standard of $6 \mathrm{~min}$. The sensitive volume of the detector is 0.271 and the sensitivity of the detector is $0.01 \mathrm{cpm}$ per $\mathrm{Bq} / \mathrm{m}^{3}$.

A field-deployed radon/thoron monitoring device for soil gas is shown in fig. 8. The detector/monitor system can measure the specific activities of the noble gases ${ }^{222} \mathrm{Rn}$ and ${ }^{220} \mathrm{Rn}$ in soil gas continuously and/or quasi-continuously. Figure 9 shows the detector signal/spectrum of a mixed radon/thoron source obtained by a radon/thoron monitor, RTM (Streil et al., 1997a).
In geophysical prospecting of active fault zones, and in environmental monitoring in general, it showed that specific activities less than $100 \mathrm{~Bq} \mathrm{~m}^{-3}$ of ${ }^{222} \mathrm{Rn} /{ }^{220} \mathrm{Rn}$ can be measured with sampling times of $1 \mathrm{~h}$ (10\% accuracy). Autonomous operating time is 10 days. With this protocol, a detection limit of about $1 \mathrm{~Bq} \mathrm{~m}^{-3}$ is obtained. Dead time losses of the sensor are below $10 \%$ at $10^{6}$ alpha particles per second and $\mathrm{cm}^{2}$. Therefore, concentrations of radon up to $10 \mathrm{MBq} \mathrm{m}^{-3}$ can be measured. The monitor system can also integrate up to 8 sensors for physical parameters like air pressure, temperature, humidity or $\mathrm{CO}_{2}$ concentration. The principal application is to quantify pedogeological areas and to find radon migration paths in fault systems.

Apart from radon concentrations, other parameters (e.g., geochemical, geophysical and 


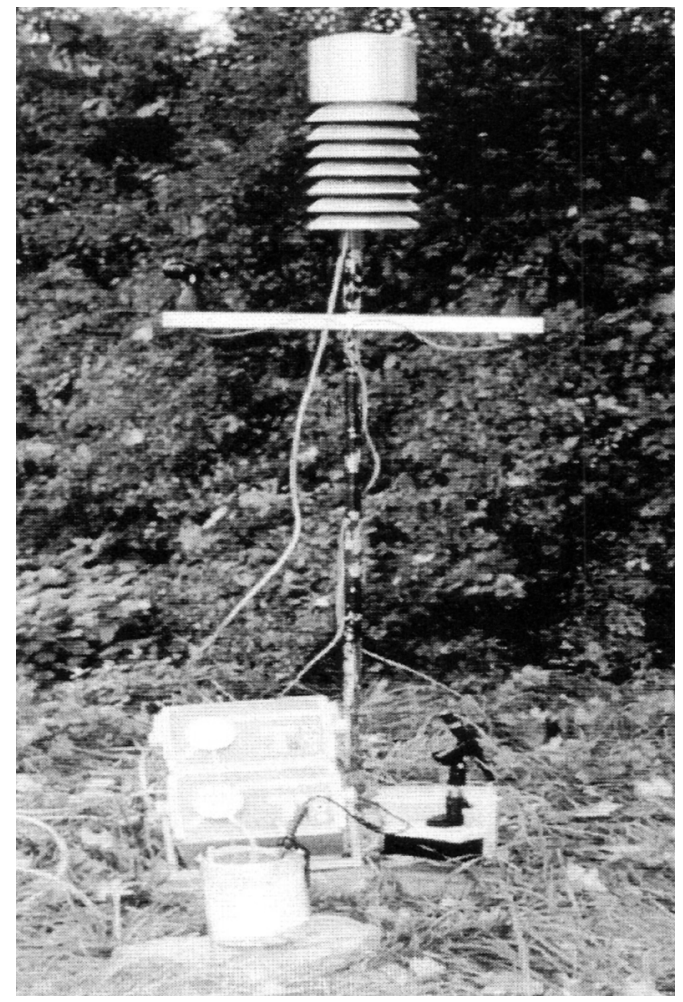

Fig. 8. A radon/thoron monitor set in the filed for radon and thoron environmental measurements in soil gas (SARAD model RM 2000 Tn, radon/thoron monitor system). hydrological) are needed in radon research. Such a system is the EPOS 1 (earthquake precursor observation system). This is a multiparameter measuring system for earthquake prediction research. It automatically and continuously records the data while sending the results to a data storage unit (Streil et al., 1997b). The combination of geochemical, geophysical and hydrological measurements includes up to $17 \mathrm{pa}$ rameters such as:

1) $\mathrm{Rn}-, \mathrm{CO}_{2^{-}}, \mathrm{N}_{2^{-}}, \mathrm{CH}_{4-}$ concentration in the gas phase;

2) Eh-value, electrical conductivity, $\mathrm{pH}$-value, $\mathrm{Rn}$-concentration in waters;

3) Water temperature, discharge observations, water level fluctuations;

4) The exhausting rate of the spring/well, and;

5) Self-potential signals, microseismicity.

A further set of sensors records meteorological parameters, such as air temperature, barometric pressure and relative humidity.

\section{Conclusions}

The major methods and techniques for measuring radon and radon decay products in radon research for geophysical, geochemical and hydrological studies have been reviewed with regard to the measurement principle, field applicability, degree of convenience, sensitivity

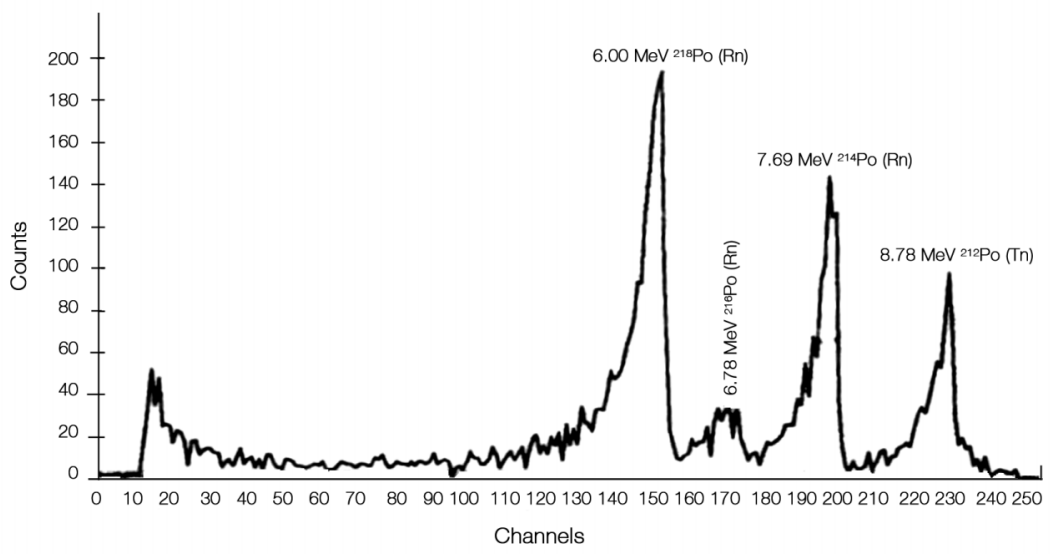

Fig. 9. Alpha spectrum of a mixed radon and thoron source obtained by a radon/thoron monitor. 
and accuracy. The three main categories of sampling and measurement, grab or instantaneous, integrating and continuous have been described. The information provided should help in the appropriate selection of an instrument that closely serves user needs and should provide instrument developers (manufacturers) with sufficient background knowledge to undertake the research necessary to improve them.

The present state of the art in the measurement of radon and radon decay products has been developed to the point where there are candidate instruments for almost every conceivable field application.

\section{REFERENCES}

Abbad, S., M.C. Robe, M. Bernat and V. Labed (1995): Influence of meteorological and geological parameter variables on the concentration of radon in soil gases: Application to seismic forecasting in the ProvenceAlpes-Côte d'Azur Region, Environ. Geochem. Health, 16S, 35-48.

Alter, H.W. and R.E. Fleischer (1981): An overview of instrumentantion for measuring environmental radon and radon progeny, IEEE Trans. Nuclear Sci., 37, 892901.

Kotrappa, P., T. Brubaker, J.C. Dempsey and L.R. StiefF (1992): Electret ion chamber system for measurement of environmental radon and environmental gamma radiation, Radiat. Prot. Dosim., 45, 107-110.

Pane, M.B., J.L. Seidel, M. Monnin and J.P. Morin (1995): Radon as a tracer of fluid motion in fractured aquifers, Environ. Chem. Health, 16S, 325-334.

Papastefanou, C., M. Manolopoulou, S. Stoulos, A. IOANNIDOU and E. GERASOPOULOS (2001): Radon measurements along active faults in the Langadas Basin, Northern Greece, Nat. Hazards Earth Syst. Sci., 1, 159164.

PinAult, J.-L. and J.-C. BAubron (1996): Signal processing of soil gas radon, atmospheric pressure, moisture and soil temperature data: a new approach for radon concentration modelling, J. Geophys. Res., 101 (B2), 31573171.

Streil, T., G. Just, G. Holfeld, V. Oeser and K. SchoeneFELD (1997a): SARAD RM 2000 Tn: a new microsystem based monitoring system for the measurement of radon and thoron in soil gas and water, in Proceedings of the 3rd International Conference on Rare Gas Geochemistry, 10-14 December 1995, Amritsar (India), 357-363.

Streil, T., J. Heinecke, U. Koch, V. Oeser and J. Wiegand (1997b): EPOS 1-A multiparameter measuring system for earthquake prediction research, in IVth International Conference on Rare Gas Geochemistry, 8-10 October 1997, Rome (Italy).

Trique, M., P. Richon, F. Perrier, J.P. Avouac and J.C. SABRouX (1991): Radon emanation and electric potential variations associated with transient deformation near reservoir lakes, Nature, 399, 137-141.

WAKITA, H., Y. NAKAMURA and Y. SANO (1998): Short-term and intermediate-term geochemical precursonrs, Pure Appl. Geophys., 126, 267-278. 